\title{
Enhancing The Mathematical Communication Ability and Self-confidence of Junior High School Students Using Brain-Based Learning
}

\author{
Sri Solihah, Heris Hendriana, Rippi Maya \\ MTsN 2 Ciamis, IKIP Siliwangi Bandung, IKIP Siliwangi Bandung \\ srisolihah1@gmail.com, herishen@gmail.com, rippimaya@gmail.com
}

\begin{abstract}
This research is motivated by the fact shows the mathematical communication ability of the students not yet in accordance with the expected. One such problem is learning that does not provide flexibility to students to exploit the potential of the brain optimally, where in general is generally more emphasis on the left brain function. Mathematical communication skills need to be supported by right brain function. Characteristics of learning that offers learning concepts that align the way the brain works naturally designed is by learning Brain-Based Learning (BBL). The research method used is quasi experiment. Quantitative data is obtained from pretest and posttes data. Research found that There are achievements and improvements in students' mathematical communication skills whose learning uses the Brain-Based Learning approach compared with students who received conventional learning in terms of students' early math skills, and self-confidence and there is an association between the ability of mathematical communication and self-confidence.
\end{abstract}

Keywords: Brain-Based Learning, Mathematical Communication, Selfconfidence.

\section{INTRODUCTION}

The Mathematical communication ability as an essential learning mathematics outcome should be improved on high school students. That statement was in line with the goals of (KTSP, 2006) Those goals among other things were: to communicate mathematically, to use mathematics as a tool for communicating, to make relation or problem by usingsymbol, table, diagram, or other media. Further, by referring to same writer's opinions (Sumarmo, 2015) identified some indicators of mathematical communication ability namely: a) to express situation, figure, diagram, or a real situation into mathematical language, symbol, idea, or model; b) to explain or clarify mathematical ideas, situation, and relation either oral or written; c) to listen, to discuss, and write about mathematics; and d) to read written mathematical representation meaningfully. According (Rosita, 2008), Mathematical communication plays an important role in the problemsolving process. Through communication the idea can be an object resulting from a reflection, refinement, discussion, and development.

One approach to learning that has characteristics that fit the above indicator is the Brain-Based Learning approach (BBL). The Brain-Based Learning model is a learning model designed to empower students' brain potential, one of which is by creating a fun 
learning environment, the brain is designed to naturally learn. According to who have many books and articles on brain-based learning, have stated the core principles of brainbased learning Caine \&Caine (Gozuyesil, 2014). According to Jensen (2008, p.483), Learning in a brain-antagonistic environment can leave one feeling threatened, over or under challenged, and therefore frustrated or boredBBL is more a toolbox than a template (chart pattern). Therefore, if viewed as a learning approach, then BBL is a learning toolbox that gives students the freedom to develop their potential naturally, that is based on the way each brain worksThus, the BBL approach leads the students to learn optimally by optimizing their brain function.

Three important instructions when applying the Brain-Based Learning approach in the classroom according to Caine et al (2005, pp.4-6) are as follows. First, relaxed alertness, which seeks a state in which the student can be "alert but relaxed". It is useful to eliminate students' fear, while keeping the environment interesting and challenging for them. According to the description Jensen (1998, p.57) Optimal learning occurs when students are at stress levels that are relaxed alertness. Second, orchestrated immersion namely to create a learning environment that truly makes students feel they have entered into an educative experience directly. Third, active processing, an activity that enables students to actively view, consolidate and internalize incoming information. According to Jensen (Nur, 2008), Brain-based Learning considers what is natural for our brains and how the brain is affected by the environment and experience. So, Brain-Based Learning is a learning based on how the brain works when the brain works optimally, then at that time effective learning can be implemented. Learning is done to challenge students' thinking skills supported by enjoyable learning and with students who are actively involved in learning.

Based on the principles of BBL, Duman (2006, p.23) found that learning with the BBL approach not only enhances academic achievement but also provides good motivation for students and teachers with a conducive classroom atmosphere, joint ventures, and interests.

There were some variables that potentially influenced the attainment of good grade on mathematics learning, among them was Self-Confidence. Confidence is an attitude that arises from the desire to manifest itself to act and succeed. In terms of development, confidence can arise thanks to the recognition of the environment (Dimyati and Mudjiono, 2009). Confidence will come from an individual's consciousness that the individual has a determination to do whatever he has to do, until the goal he wants to achieve. The determination to do something is followed by a sense of confidence that he has the ability to achieve the desired goals.

\section{RESEARCH METHOD}

This study was intended to examine the role of prior mathematics ability (PMA) and Brain-based Learning (BBL) to the achievement of mathematical communication ability (MCA) and self-confidence (SC) of junior high school students. The research method used is quasi experiment, with student population of class VIII MTsN Ciamis which consists of seven classes and taken two classes as research sample. The instruments of this study were an essay test on mathematical communication and selfconfidence scale. The sample items of MCA test and SC scale, are as follows: 


\section{Sample Items of Mathematical Communication Ability Test}

1. Examples of communication skills for indicators Prepare questions about a given situation with reasons

For example known SPLDV

$2 x+3 y=5.700$

$x+2 y=3.300$

Make a story of everyday problems that is consistent with the given SPLDV) ! Pose a question about the stories that you create and can be answered with complete SPLDV

2. Sample statements of self-confidence scale.

Note: QO : Strongly diasagree

$S$ :agree

$\mathrm{O}$ : diasagree

QS :Strongly agree

Table 1. Sample Items of Self-Confidence

\begin{tabular}{|c|c|c|c|c|c|}
\hline No & Statement & QO & $\mathrm{O}$ & $\mathrm{S}$ & QS \\
\hline 1 & I extend my own opinion in forum discussion & & & & \\
\hline 2 & I learn mathematics because I love it & & & & \\
\hline 3 & I am affraid to pose a question to mathematics teacher & & & & \\
\hline 4 & I feel confident that I will succeed in the mathematics test & & & & \\
\hline 5 & I feel nervouse when solving a problem in front of class & & & & \\
\hline 6 & I feel challenged when I face a complicated problem of SPLDV & & & & \\
\hline 7 & I feel asshamed to solve a problem in the front of the class & & & & \\
\hline 8 & I feell, brave to defend my own opinion in front of the class & & & & \\
\hline
\end{tabular}

\section{RESULTS AND DISCUSSION}

Mathematical communication ability (MCA), self-confidence (SC), and BrainBased Learning (BBL) were presented in Table 2. Before the intervention, students were grouped based on their grades on PMA Maya (2011): high $(x>70)$, medium $(55<x \leq 70)$ and low $x \leq 55$. Table 2 for the achievement of mathematical communication ability of MTs students whose learning using Brain-Based Learning model and conventional approach show the overall difference, Meanwhile, in the posttest, student taugth by BBL obtained fairly good grades on MCA $(13,76$ or $68,76 \%$ out of ideal score) wich were better than students' grades in Conventional group (11,12 or $55,61 \%$ out of ideal score).

Moreover, on the n-Gain MCA, the result showed students taught by the BBL gained greater grades on $n$-Gain MCA $(0,58)$ than their fellow students taught by the conventional teaching $(0,44)$. Analyses of mean differences of MCA and N-Gain MCA for the whole students in both groups were presented in Table 3. 
Table 2. Mathematical CommunicationAbility based on Prior Mathematics Ability and Teaching-Learning Approach

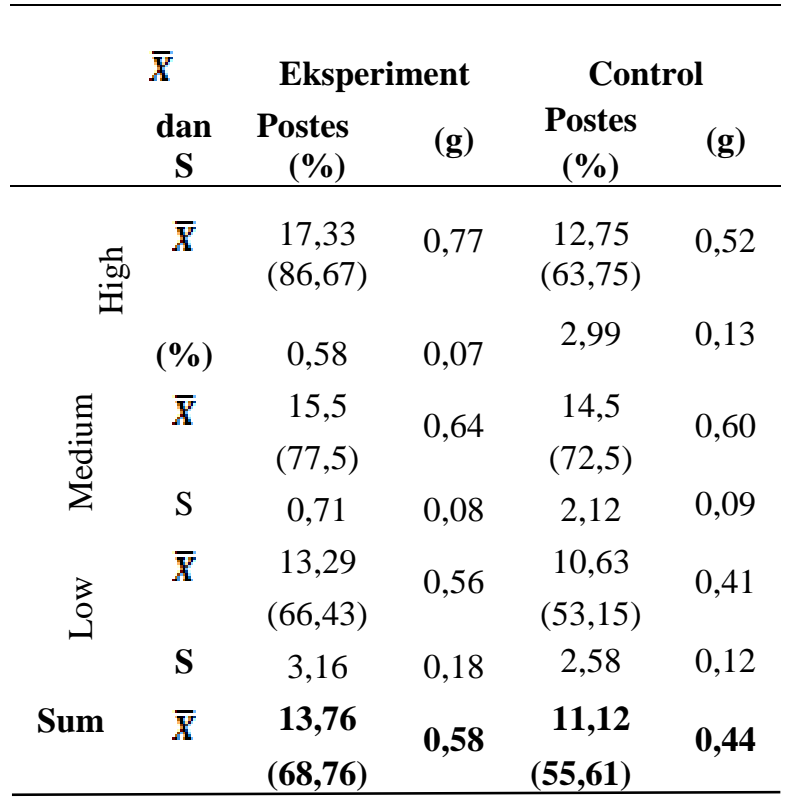

Table 3.Testing of Hypotesis of mean Difference of MCA, N-Gain of MCA, and $\mathrm{SC}$ in BBL and Conventional Teaching

\begin{tabular}{cccccc}
\hline $\begin{array}{c}\text { Vari- } \\
\text { abel }\end{array}$ & $\begin{array}{c}\text { Teaching } \\
\text { Approach }\end{array}$ & $\overline{\boldsymbol{X}}$ & SD & N & Sig. \\
\hline \multirow{2}{*}{ MCA } & BBL & 13,76 & 3,16 & 33 & \\
& Conv & 11,12 & 2,90 & 33 & 0,000 \\
\multirow{2}{*}{ n-Gain MCA } & BBL & 0,58 & 0,17 & 33 & \\
& Conv & 0,44 & 0,14 & 33 & 0,000 \\
SC & BBL & 72,91 & 9,18 & 33 & 0,290 \\
& Conv & 69,33 & 7,60 & 33 & \\
\hline
\end{tabular}

Note:MCA is Mathematical Communication Ability; Ideal Score of MCA 20. n-Gain is normalized gain; SC is Self-Confidence; Ideal Score 120.(Solihah, 2018)

Analysis of MCA for each level of PMA was presented in Table 3 for both groups. The Table demonstrated the correlation between PMA wich MCA and n-Gain MCA; the higher students' grades PMA, the higher their grades on MCA and n-Gain MCA.This indicated the supremacy of students' PMA in affecting their grades on MCA and n-Gain. These findings supported the hypotesis that having a well understanding on a particular mathematical content will lead students to be more succes in further comprehension or other mathematics contents. As for students with medium and high PMA, their grades on MCA were higher in the goup thauhgt by BBL than students' grades from Conventional teaching. Moreover, students with low PMA and getting teaching on BBL attained better grades $(15,5$ or $77,5 \%$ out of ideal score) than the grade of students with high PMA taught by Conventional teaching (12,75 or $63,75 \%$ out of ideal score). Table 4 showed that there was no differences in SC grades between students taught by BBL (72, 91 or 60 , 
$76 \%$ out of ideal score) and students taught by conventional teaching $(69,33$ or $57,78 \%$ out of ideal score). Analysis of mean differences of the acheiment on SC was presented in Table 5. However, students with low, medium and high PMA given BBL were better on SC grades than students given intervention using conventional teaching.

Table 4. Self-Confidence based on Prior Mathematics Ability and Teaching-Learning Approach

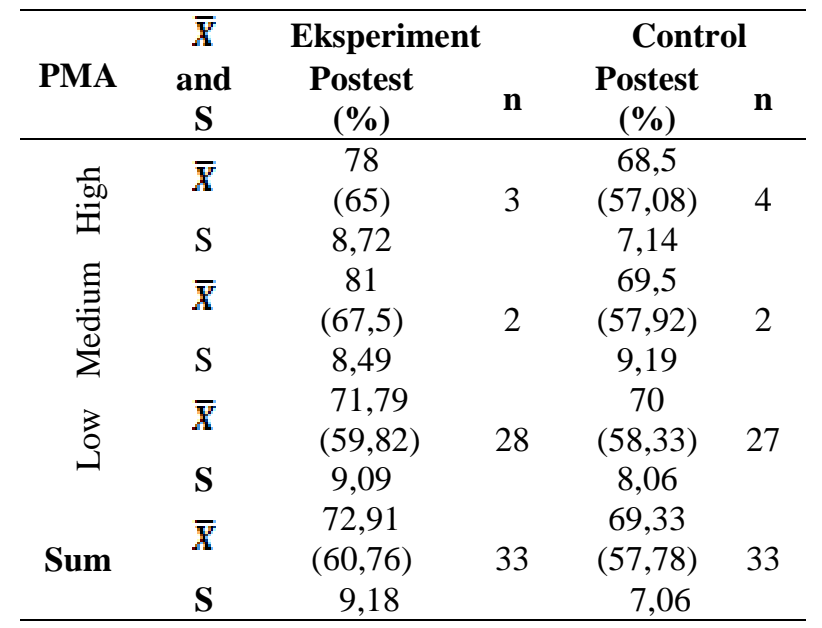

(Solihah,2018)

Having computed analysis correlation between MCA and SC (Presented in Table 5), the study found out $\chi^{2}=27,433$ and $\mathrm{C}=0,664$ indicated that there was moderate correlation between BBL and SC (presented in Table 6). This finding was similar to the finding of several previous studies (Qohar, 2010; Wardani, 2010; Yonandi, 2010; Sritresna, 2017), although it was different with the findings of other studies (Sumarmo, Hidayat, Zulkarnaen, Hamidah, \& Sariningsih, 2012; Sumaryanti, 2013; Rahmat, 2014; Hendriana, 2014)) that there were no correlation between cognitive and affective component of mathematics learning outcome. Further analysis on the role PMA and the applied teaching learning approaches generated a result that there was no relation between PMA and teaching approaches on mathematical communication.

Table 5.The number of students in each Level of MCA and $\mathrm{SC}$ in Communications class.

\begin{tabular}{llllll}
\hline & \multicolumn{4}{c}{ Self-confedence } & \multirow{2}{*}{ Total } \\
& & High & Medium & Low & Total \\
\hline \multirow{3}{*}{ MCA } & High & 6 & 17 & 0 & 23 \\
\hline \multirow{3}{*}{ Total } & Medium & 1 & 9 & 6 & 16 \\
\hline & Low & 0 & 9 & 18 & 27 \\
& & 7 & 35 & 24 & 66 \\
\hline
\end{tabular}


Table 6.Testing Hypotesis of Association between Mathematical Communications Ability and Self-confidence

\begin{tabular}{lccc} 
& Value & $\begin{array}{c}\text { Approximate } \\
\text { Significance }\end{array}$ \\
\hline Nominal by Nominal & Contingency Coefficient & 542 &, 000 \\
N of Valid Cases & 66 & \\
\hline In Addition to superiority of Brain-Based Learning (Solihah,2018)
\end{tabular}

\section{CONCLUSION}

Brain-Based learning played a better role than the prior mathemtics ability on the acheivement of mathematical communications ability and its n-Gain, and on attainment of self-confidence. There are achievements and improvements in the mathematical communication skills of students whose learning used a Brain-Based Learning approach compared to students who received conventional learning in terms of students' early math skills, and Self-Confidence.

The overall students, both with low and medium prior mathematics ability, taught by Brain-Based Learning better grades on mathematical Communicatins ability, on its nGain, and on self-confidence than another group. Students' grades on mathematical communication ranged from averge to fairly good and their gradeson self-confidence were relatively good. Moreover, that there were no correlation between cognitive and affective component of mathematics learning outcome. Further analysis on the role PMA and the applied teaching learning approaches generated a result that there was no relation between PMA and teaching approaches on mathematical communication.

The Sudy found that students' prior mathematics ability affected the attainment of mathematical communication ability and its n-Gain well. Therefore, teacher has to pay more attention on comprehending the prerequisite materials of mathematics before teaching the more complex materials. The grades of self-confidence of students were still average. Improving students'self-confidence a continuous process. Similar to development of value and character, there are four ways for improving students selfconfidence of the students: a) teacher makes students recognize the understanding of the expected behavior; b)students are accustomed to expected behavior; c) teacher should model the expected behavior; d) teaching and learning should be conducted integratedly and continously. 


\section{REFERENCES}

Depdiknas, (2003). Kurikulum 2006: Kurikulum Tingkat Satuan Pendidikan. Jakarta; Depdiknas.

Dimyati \& Mudjiono. (1999). Belajar dan Pembelajaran . Jakarta: Rhineka Cipta

Duman, B.(2006). The Effect of Brain-Based Instruction to improve student's academic achievement in social studies instruction. $9^{\text {th }}$ International Conference on Engineering Education, San Juan, 24, 1725.

Gozuyesil, E. dikici ayhan. (2014). The Effect of Brain Based Learning on Academic Achievement: A Meta-analytical Study. Educational Sciences: Theory \& Practice, 14(2), 642-648. https://doi.org/10.12738/estp.2014.2.2103

Hendriana, H. (2013). Membangun Kepercayaan Diri Siswa melalui Pembelajaran Matematika Humanis. Paper presented at National Seminar on Mathematics Education at Siliwangi School of Teacher Training and Education, Bandung.

Hendriana, H.Rahmat, U. Sumarmo, U. (2014). Mathematical Connection Ability and Self-confidence (An Experiment on junior High School Students Through Contextual teaching and Learning with Mathematical Manivulative. International Journal of Education Universitas Pendidikan Indonesia. Vol.8. no.1

Jensen, E. (2008). Brain-Based Learning. Yogyakarta: Pustaka Pelajar.

Maya, R. (2011). Pengaruh Pembelajaran dengan Metode Termodifikasi terhadap Pencapaian Kemampuan Pemahamandan Pembuktian MatematikMahasiswa. Disertasi pada SPS UPI. Bandung: Tidak diterbitkan.

Nur,I.R.D.(2016). "Meningkatkan Kemampuan Berpikir Kritis Matematis dan Kemandirian Belajar Siswa dengan Menggunakan Model Pembelajaran Brain Based Learning". Jurnal Pendidikan UNISKA. Vol. 4. pp. 26-41.

Qohar, A. (2010). Mengembangkan Kemampuan Komunikasi Matematis dan Kemandiria Belajar Siswa SMP melalui Reciprocal Teaching. (Unpublished dissertation). School of Posgraduated Studies, Indonesia University of education, Bandung.

Rachmat, U.S .(2014). Meningkatkan kemampuan koneksi dan pemecahan masalah matematik serta kepercayaan diri siswa SMP melalui pembelajaran Kontekstual berbantuan Mathematical Manipulative. (Unpublished thesis). Postgraduste Study, Siliwangi School of Teacher Training and Education, bandung.

Gozuyesil, E. dikici ayhan. (2014). The Effect of Brain Based Learning on Academic Achievement: A Meta-analytical Study. Educational Sciences: Theory \& Practice, 14(2), 642-648. https://doi.org/10.12738/estp.2014.2.2103

Rosita, C. D. (2008). Kemampuan Penalaran Dan Komunikasi Matematis : Apa, Mengapa, Dan Bagaimana Ditingkatkan Pada Mahasiswa. Jurnal Euclid, Vol.1, No.1, 1(1), 1-2.

Sritresna, T. (2017). Meningkatkan Kemampuan Komunikasi Matematis dan SelfConfidence Siswa Melalui Model Pembelajaran Cycle 7E. Mosharafa, 6(September 2017), 419-430.

Solihah, S. (2018) Meningkatkan Kemampuan Komunikasi dan Berpikir Kritis Matematik sertaSelf-Confidence Siswa Mts dengan Menggunakan Pendekatan Model Brain-Based Learning. (unpublished thesis). Postgraduate study, Siliwangi School of Teacher Training and Education, Bandung. (in progress) 
Sumarmo, U. (2014). Kumpulan Makalah Berpikir dan Disposisi Matematik serta Pembelajarannya. FPMIPA UPI. Bandung: Tidak diterbitkan.

Sumarmo, U. (2015). Kemampuan-kemampuan Afektif [Online]. Tersedia: http://utarisumarmo.dosen.stkipsiliwangi.ac.id [Diakses 5 Desember 2017].

Sumarmo,U.,Hidayat, W., Zulkarnaen, R., Hamidah, \& Sariningsih, R. (2012). Mengembangkan Kemampuan dan Disposisi Berpikir Logis, Kritis, dan Kreatif matematik Siswa SMA melalui Pembelajaran Berbasis Masalah dan Strategi ThinkTalk-Wraite. Research report at STKIP Siliwangi Bandung. In U. Sumarmo.

Sumaryanti, E. (2013). Pendekatan Indiktif Deduktif disertai Strategi Think-Pair SquareShare untuk Meningkatkan Kemampuan Pemahaman dan Berpikir Kritis Matematis Siswa SMA. (Unpublished thesis). School of Postgraduate Studies, Indonesia University of Education, Bandung.

Turmudi (2009). Taktik dan Strategi Pembelajaran Matematika. Jakarta: Lauser Cipta Pustaka

Wardani, S. (2010). Meningkatkan Kemampuan Berpikir Kreatif dan Disposisi Matematik Siswa SMA Melalui Pembelajaran dan Pendekatan model Sylver. (Unpublished disssertation). School of Postgraduate Studies, Indonesia University of Education, Bandung. 